УДК 006.86.664.93

(C) 2017

Гавриленко О. С., кандидат ветеринарних наук, Хоміцька О. А., завідувач сектору мікробіологічних випробувань, Загорулько О. В., старший науковий співробітник

Український державний науково-дослідний інститут «Ресурс», м. Київ

\title{
МІКРОБІОЛОГІЧНИЙ КОНТРОЛЬ М'ЯСНИХ ТА М'ЯСОРОСЛИННИХ КОНСЕРВІВ
}

\section{Рецензент - кандидат ветеринарних наук В. М. Муковоз}

У статті наведено результати досліджень якості 22-х зразків м'ясних та м'ясорослинних консервів украӥнських виробників за органолептичними, фізикохімічними та мікробіологічними показниками. Проаналізовано показники якості та безпечності консервів, щуо реалізуються в торговій мережі по Україні. За результатами проведених досліджень встановлено невідповідності згідно з діючими стандартами за органолептичними, фізико-хімічними та мікробіологічними показниками, щчо свідчить про порушення на етапах виробництва дослідних зразків консервів українських підприємств-виробників.

Ключові слова: м'ясо, м'ясорослинні консерви, якість, безпечність, мікроорганізми, невідповіднiсть.

Постановка проблеми. У сучасних умовах ринкових відносин розширюється спектр готових до вживання м'ясних продуктів. Найчастіше це консерви із м'яса та м'ясорослинні - каші 3 м'ясом. Вони відрізняються високою харчовою цінністю, тривалим терміном зберігання (до 3-5 років) та зручністю транспортування. Проте часто під час вживання виникають сумніви щодо їх якості та безпечності, встановленим критеріям згідно з вітчизняними і європейськими нормативними документами (ЄС). Ціни великі, а якість консерви протягом терміну зберігання не відповідає $[1,11]$. Стало більше фальсифікацій - неякісна низькосортна сировина замість м'яса вищого гатунку [18]. В останні роки ця проблема стає ще більш актуальною.

Аналіз основних досліджень і публікацій, у яких започатковано розв'язання проблеми. Ринок м'ясних консервів є одним з найбільших ринків продовольчих товарів в Україні. М'ясні консерви відносяться до числа цінних харчових продуктів, «які замінюють» свіже м'ясо і є одним 3 основних постачальників організму людини повноцінними білками, необхідними для побудови тканин, органів і забезпечення фізіологічних процесів. М'ясні консерви користуються великим попитом у покупців, тому що є продуктом готовим до вживання 3 терміном зберігання до п'яти років. Але з розвитком ринкової економіки, проблем 3 якістю консервів стало більше. Сформувалася важка ситуація через недостатню якість сировини, недотримання технологічного процесу виробництва та рецептур, порушення умов зберігання, що впливає на зниження якісних показників готового продукту $[1,18]$. Визначення якості м'ясних консервів $є$ перспективним та актуальним напрямом, оскільки ці продукти мають енергетичну цінність та комфортність вживання. Забезпечити контроль якості м'ясних та м'ясорослинних консервів можливо завдяки комплексному дослідженню мікробіологічних, органолептичних та фізико-хімічних показників для встановлення відповідності вимогам чинних нормативних документів, орієнтованих на міжнародні та європейські стандарти. Це є складовою частиною системи технічного регулювання та забезпечення якості продукції, що реалізовується на ринках України [18-21].

Мета досліджень - встановити відповідність м'ясних та м'ясорослинних консервів нормативним документам за органолептичними, фізикохімічними та мікробіологічними показниками.

Завдання дослідження:

1. Провести дослідження на якість і безпечність м'ясних і м'ясорослинних консервів згідно 3 нормативною документацією національних та європейських стандартів [15, 16].

2. Визначити основні причини невідповідностей критеріїв безпеки для досліджених консервів згідно $з$ діючими стандартами.

Матеріали і методи досліджень. Об'єктами досліджень були 22 зразки м'ясних та м'ясорослинних консервів: «Яловичина тушкована», «Свинина тушкована», «Каша перлова 3 яловичиною», «Каша рисова 3 яловичиною», «Сніданок туриста. Яловичина», «Каша перлова 3 яловичиною», «Каша гречана 3 яловичиною» та «Паштет печінковий із свинячим жиром» виробників ТОВ «Візит», ТОВ «М'ясокомбінат «Куп'янський», ТОВ «Буський консервний завод», ТОВ ТПК «Грін Рей» та ТОВ «Охтирка 


\section{СІЛЬСЬКЕ ГОСПОДАРСТВО. ТВАРИННИЦТВО}

м'ясопродукт». Зразки були відібрані згідно 3 актом випадкового відбору харчових продуктів і доставлені в лабораторію УкрНДІ «РЕСУРС», де і проводились експертні дослідження. Лабораторія акредитована Національним агентством 3 акредитації України на технічну компетентність та незалежність згідно зі стандартом ДСТУ ISO/IEC 17025:2006 [12], що дає їй право проводити випробування харчових продуктів та продовольчої сировини на відповідність вимогам чинної нормативної документації.

Комплексне дослідження консервів проводили на відповідність ДСТУ 4607:2006 «Консерви м'ясо-рослинні. Каші з м'ясом. ЗТУ» [16], ДСТУ 4450:2005 Консерви м'ясні «М'ясо тушковане. ТУ $\gg$ [15], ГОСТ 8756.1-2015 [9], ДСТУ 4939:2008[17], ГОСТ 8756.4-70 [10] за органолептичними показниками: зовнішній вигляд, колір м'яса, колір та вигляд м'ясного соку у нагрітому стані, консистенція, запах та смак, за фізикохімічними показниками: масова частка кухонної солі, масова частка жиру, сторонні домішки.

За мікробіологічними показниками промислової стерильності досліджували згідно з ГОСТ 30425-97 [7]. У цьому стандарті подано методики дослідження на промислову стерильність усіх видів консервів. Згідно зі стандартом проводили визначення зовнішнього вигляду і герметичності консервів, дослідження загальної кількості життєздатних мікроорганізмів, бактерій груп $B . s u b$ tilis, B. cereus $i$ B. polymyxa, мезофільних клостридій $C$. botulinum $i C$. perfringens, неспороутворючих бактерій, коків, дріжджів, плісняви грибів та термофільних мікроорганізмів в 1 г. У стандарті $є$ посилання на нормативні документи ГОСТ 10444.7-86, ГОСТ 10444.8-2013, ГОСТ 10444.988, ГОСТ 10444.12-2013, ГОСТ 10444.15-94, ГОСТ 30518-97, ДСТУ ISO 6888-1:2203, ДСТУ ISO 6888-2:2003 [2-6, 8, 13, 14], згідно з якими встановлюється відсутність перечислених мікроорганізмів.

Результати досліджень. За результатами проведених випробувань консерви м'ясо-рослинної «Каша перлова 3 яловичиною» та м'ясної «Сніданок туриста. Яловичина» виробника ТОВ ТПК Грін Рей» за перевіреним фізико-хімічним показником: масова частка кухонної солі, \% - не відповідає вимогам ДСТУ 4607:2006. За результатами випробувань масова частка кухонної солі в консервах значно перевищує норму або нижче норми $(1,9 \%$ та 0,9\%) за норми - від 1,0 до $2,0 \%$.

Консерви м'ясні стерилізовані «Яловичина тушкована» виробника ТОВ ТПК «Грін Рей» за перевіреними органолептичними показниками: зовнішній вигляд, колір м'яса, колір та вигляд м'ясного соку у нагрітому стані, консистенція, та фізико-хімічним показником - масова частка жиру, \% - зразок не відповідає вимогам стандарту. Шматочки м'яса, в основному, масою менші ніж 30 г, колір м'яса та м'ясного соку у нагрітому стані червоний (в нормі м'ясо та м'ясний сік у нагрітому стані сірого кольору 3 коричневим та рожевим відтінками різної інтенсивності з наявністю завислих білкових речовин у вигляді пластівців). М'ясо переварене, фаршоподібне, що не допускається для вищого сорту (воно повинно бути соковите, не переварене під час обережного виймання 3 банки шматочки не розпадаються). Масова частка жиру - 22,3 \%, що перевищує норму (для вищого сорту - 17,0 \%).

Під час дослідження консервів м'ясних «М'ясо тушковане «Яловичина тушкована»» виробника ТОВ «Охтирка м'ясопродукт» за перевіреними органолептичними показниками: зовнішній вигляд, консистенція та фізико-хімічним показником: масова частка жиру, \% - зразок теж не відповідає вимогам ДСТУ 4450:2005. Шматочки, переважно, масою менше ніж 30 г, м'ясо переварене, під час обережного виймання з банки шматочки розпадаються. Масова частка жиру - 23,1 \%, що перевищує норматив на 6,1\%.

Консерви м'ясні «Яловичина тушкована» виробника ТОВ «Візит» за перевіреними органолептичним показниками: зовнішній вигляд, консистенція, запах та смак теж не відповідали вимогам стандарту. М'ясо тушковане шматочками, переважно, масою меншою ніж 30 г, переварене, під час обережного виймання 3 банки шматочки частково розпадалися, запах кислий, смак не властивий тушкованому м'ясу, без аромату прянощів, притаманним зіпсованому м'ясу.

Під час дослідження консерви «Сніданок туриста (яловичина)» виробника ТОВ «Візит» за органолептичними показниками (зовнішній вигляд, консистенція, колір) - консерва не відповідає вимогам стандарту. Шматочки м'яса 3 наявністю виплавленого жиру без желе (в нормі обов'язково желе жовтуватого кольору ніжної консистенції), в наявності шматочки сполучної тканини. М'ясо від рожевого до червоного кольору, за норми - сірий колір 3 коричневим та рожевим відтінками різної інтенсивності.

За мікробіологічними показниками промислової стерильності всі консерви, крім «Паштету печінкового із свинячим жиром» виробника ТОВ «Візит», відповідали вимогам ГОСТ 30425-97. 3 паштету було висіяно патогенний стафілокок, що свідчить про забрудненість продукту та недостатню стерилізацію. 


\section{СІЛЬСЬКЕ ГОСПОДАРСТВО. ТВАРИННИЦТВО}

Під час дослідження зразків консервів «М'ясо тушковане «Свинина тушкована» ТОВ «Буський консервний завод», «Свинина тушкована» ТОВ «М'ясокомбінат «Куп'янський», м'ясо-рослинних консервів - «Каша гречана 3 яловичиною» та «Каша перлова 3 яловичиною» виробника ТОВ «Візит» порушень не виявлено. Всі зразки за перевіреними органолептичними, фізикохімічними та мікробіологічними показниками відповідали вимогам стандартів.

\section{Висновки:}

1. За мікробіологічними показниками всі зразки консервів, окрім «Паштету печінкового із свинячим жиром» виробника ТОВ «Візит», відповідали вимогам промислової стерильності. 3 паштету було висіяно патогенний стафілокок, що свідчить про порушення санітарногігієнічних вимог технологічного процесу підготовки, фасування в банки та недостатню стерилізацію.

2. За результатами проведених випробувань за перевіреними органолептичними показниками: зовнішній вигляд, колір м'яса, колір та вигляд м'ясного соку у нагрітому стані, консистенція, колір, запах та смак консерви та за перевіреним фізико-хімічним показником: масова частка жиру, \% масова частка кухонної солі, \% виробника ТОВ ТПК «Грін Рей», ТОВ «Візит» та ТОВ «Охтирка м'ясопродукт» не відповідає вимогам нормативних стандартів та свідчить про те, що м'яco, закладене в банки було не достатньо якісним

\section{БІБЛІОГРАФІЯ}

1. Асенова Б. К. Технология производства функциональных продуктов питания для экологически неблагоприятных регионов. Торговоэкономические проблемы регионального бизнеспространства / Б. К. Асенова, К. Ж. Амирханов, М. Б. Ребезов. - 2013. - №1. - С. 313-316.

2. ГОСТ 10444.7-86 Продукты пищевые. Методы выявления ботулинических токсинов и Clostridium botulinum (Дата последнего изменения : 13.07.2017).

3. ГОСТ 10444.8-2013 Микробиология пищевых продуктов и кормов для животных. Горизонтальный метод подсчета презумптивных Bacillus cereus. Метод подсчета колоний при температуре $30<$ град>C.

4. ГОСТ 10444.9-88 Продукты пищевые. Метод определения Clostridium perfringens.

5. ГОСТ 10444.12-2013 Микробиология пищевых продуктов и кормов для животных. Метод выявления и подсчета количества дрожжей и плесневых грибов.

6. ГОСТ 10444.15-94 Продукты пищевые. Ме- i були порушення на етапах технологічних операцій виробництва - підготовки і обробки, порціювання і фасування сировини.

3. Результати досліджень дали змогу виявити явні порушення Закону України «Про захист прав споживачів» і можна зробити висновок, що треба проводити частіше маркетингові дослідження якості м'ясних консервів, щоб український споживач знав, що він купує і які проблеми можуть бути, оскільки продукти 3 м'яса стають все більш популярними на території України.

Перспективи подальших досліджень. Попередити можливі негативні наслідки під час виробництва м'ясної продукції можна лише за умови здійснення комплексних досліджень на етапах виробництва, зберігання, транспортування та реалізації. Під час виробництва слід застосовувати систему НАССР, засновану на аналізі ризиків та контролю в критичних точках етапів виробництва.

Встановлення в організації-виробника постійного контролю виробництва м'ясних консервів 3 урахуванням оцінки ризиків системи НАССР та маркетингові дослідження якості харчової продукції відповідає сучасним міжнародним принципам і сприяє гарантії безпечності для споживача. Це є гарантією отримання готової м'ясної продукції, яка відповідатиме стандартам якості і дасть можливість попереджати порушення технологічних режимів виробництва.

тоды определения количества мезофильных аэробных и факультативно-анаэробных микроорганизмов (Дата последнего изменения : 13.07.2017).

7. ГОСТ 30425-97 Консервы. Метод определения промышленной стерильности.

8. ГОСТ 30518-97 Продукты пищевые. Методы выявления и определения количества бактерий группы кишечных палочек (колиформных бактерий).

9. ГОСТ 8756.1-2015 Консервы мясные и мясосодержащие. Методы определения органолептических показателей, массы нетто и массовой доли составных частей.

10. ГОСТ 8756.4-70 Продукты пищевые консервированные. Метод определения содержания минеральных примесей (песка).

11. Губер Н. Б. Инструменты снижения рисков при реализации инновационных проектов в сфере продуктов питания животного происхождения / Н. Б. Губер, М. Б. Ребезов, Г. М. Топурия // Вестник Южно-Уральского государственного 


\section{СІЛЬСЬКЕ ГОСПОДАРСТВО. ТВАРИННИЦТВО}

университета. Серия: Экономика и менеджмент. - 2014. - T. 8. - №1. - C. 156-159.

12. ДСТУ ISO/IEC 17025:2006 Загальні вимоги до компетентності випробувальних та калібрувальних лабораторій (ISO/IEC 17025:2005, IDT).

13. ДСТУ ISO 6888-1:2003 Микробиология пищевых продуктов и кормов для животных. Горизонтальный метод подсчета коагулазоположительных стафилококков (Staphylococcus aureus и других видов). - Часть 1. Метод с использованием агаровой среды Беард-Паркера (ISO 6888-1:1999, IDT).

14. ДСТУ ISO 6888-2:2003 Микробиология пищевых продуктов и кормов для животных. Горизонтальный метод подсчета коагулазоположительных стафилококков (Staphylococcus aureus и других видов). Часть 2. Метод с использованием фибриногена плазмы крови кролика для агаровой среды (ISO 6888-2:1999, IDT).

15. ДСТУ 4450:2005 Консервы мясные. Мясо тушеное. Технические условия ДСТУ 4607:2006 Консервы мясорастительные. Каши с мясом. Общие технические условия.

16. ДСТУ 4607:2006 Консервы мясорастительные. Каши с мясом. Общие технические условия.
17. ДСТУ 4939:2008 Продукты переработки фруктов и овощей, консервы мясные и мясорастительные. Методы определения содержания хлоридов.

18. Клив де В. Блэкберн. Микробиологическая порча пищевых продуктов / Клив де В. Блэкберн. - СПб. : Профессия, 2008.

19. Коиюмбас I. Я. Експертиза напівфабрикатів м'ясних та м'ясо-рослинних січених мікроструктурним методом / І. Я. Коцюмбас, Г. І. Коцюмбас, О. М. Щебентовська // Методичні рекомендації. - Львів : Афіша, 2011. - 80 с.

20. Наказ МО3 України № 1140 від 29.12.2012 Про затвердження Державних санітарних норм та правил «Медичні вимоги до якості та безпечності харчових продуктів та продовольчої сировини».

21. Наказ МО3 України № 548 від 19.07.2012 Про затвердження Мікробіологічних критеріїв для встановлення показників безпечності харчових продуктів.

22. Про безпечність і якість харчових продуктів. Закон України від 23 грудня 1997 р. [зі змін. та доп., внесеними Законами України від 13 вересня 2001 р. № 2681-III від 24 жовтня 2002 р. № 191-IV]. 